\title{
Environmental viability for rural roads in the Amazon region, Brazil
}

\author{
J. M. C. Maciel ${ }^{1}$ \& M. P. S. Santos ${ }^{2}$ \\ ${ }^{I}$ Federal Center for Technological Education of Amazonas, Brazil \\ ${ }^{2}$ Federal University of Rio de Janeiro, Brazil
}

\begin{abstract}
The problem of transport accessibility in rural areas in the state of Amazonas, Brazil, is identified and analyzed in this paper. While rural roads are an important communication route between remote and urban areas, offering conditions for production and commercial outflow, besides better access to education, health and leisure activities, they also can encourage deforestation and uncontrolled exploitation of natural resources. The main aspects regarding rural road specificities in the state, such as local demand, transport costs to and from agricultural markets, access to education and health facilities and illegal and legal exploitation of natural resources are considered. The environmental questions raised by rural road building in the region are contrasted with public policies for economic and social development. The methodology used to establish environmental viability is based on the system dynamics technique, using information gathered on rural road characteristics to build a dynamic system map. The results suggest that the environmental viability of rural roads in the Amazon region depends on local characteristics like the type of agricultural production, transport accessibility, deforestation aspects and natural resource exploitation.
\end{abstract}

Keywords: rural roads, environmental viability, dynamic systems, rural accessibility, regional development.

\section{Introduction}

Rural roads are an important connection between remote and urban areas, enabling the outflow of products and facilitating access to education and health services and leisure activities available in towns. In the Amazon region, these 
roads make a considerable contribution to the transportation system, mitigating over-reliance on river transportation.

The importance of local roads in rural areas of the Amazon goes beyond outflow of products and supply of nearby cities and towns. These roads play an important social function by facilitating access to the outside world and providing opportunities for economic development.

However, policies to expand road systems in the Amazon region raise justified environmental concerns because they can promote migration to virgin forest areas, bringing deforestation and the establishment of various economic activities that contribute little to the sustainable development of the communities involved. The important role of rural roads for regional development and market accessibility are described and investigated by many authors [1-3].

According to Jaarsma [4], the building of local roads should be planned to harmonize the technical and use characteristics, as well as the function of the particular road, considering local people and their access to commerce, health and education, among other factors.

One of the main functions of rural roads is to carry local output. In the Amazon region considered here, this production mainly consists of plant and animal products from smallholders. In this respect, these roads are a positive factor by boosting the local productive chain, decentralizing activities and increasing work opportunities and income in remote areas of the state of Amazonas [5, 6]. From a broader perspective, the essential function of rural roads is to provide links to establish closer social and commercial relations between rural areas and towns and cities.

Public investments to build rural roads in the state of Amazonas mainly come from the state government in partnership with municipal governments. Sometimes the federal government participates as well, through the National Institute for Colonization and Agrarian Reform (Incra), based on the federal policy on rural settlement regulated by the Land Statute (Law 4504). Some roads are opened without public investments, for example by illegal loggers and land speculators.

In this article we examine the viability of building and operating rural roads, relating the environmental aspects with the economic and social ones, considering the specific characteristics of the region and its existing and proposed local roads. This entails analysis of the influence of these roads on the local productive chain and their contribution to facilitate access by rural dwellers to the services available in nearby population centers, generally the municipal seats.

\section{Methodology}

We chose the system dynamics method, developed by Jay W. Forrester [7] in 1956 and initially applied to industrial systems and business management, because it permits treatment of local factors and the agents involved in integrated form. Since its creation, this method has been developed to expand its range of possible applications and today it is considered a useful tool for treatment of a 
wide array of complex problems. The evolution of the system dynamics method, based on modelling through the representation of cause and effect relationships is described and discussed by Lane [8].

According to Checchinato [9], the system dynamics method consists of a set of thinking and computational modeling techniques that combine theories, methods and philosophies to analyze the behavior of complex systems holistically rather than divided into separate parts, to examine problems where the elements or variables that compose the system vary over time. The use of system dynamic techniques as a support for the decision making process and the definition of planning strategies is discussed by Gary et al. [10]. The application of system dynamics techniques in sustainability analysis can be seen in the work of Hjortha and Bagheria [11].

According to Leal-Neto [12], an important aspect for the use of system dynamics is the availability of computer programs that incorporate graphic computational techniques, such as Stella, Powersim and Vensim. These programs enable visualizing how variables are affected by time and different hypotheses, besides offering a simple and consistent way to describe systems and build simple simulation models, graphical diagrams and schematic maps.

We used the Vensim Software - PLE (Personal Learning Edition) program, developed by Ventana Systems, Inc. It is available for free use in education institutions. According to the program manual, Vensim is a visual modeling tool allowing users to conceptualize, document, simulate, analyze and optimize models of dynamic systems. It provides a simple and flexible way to build simulation models from causal loop or stock and flow diagrams [13].

The roads analyzed are located in the state of Amazonas and have certain peculiarities regarding type, governance, environmental characteristics, products carried, accessibility, social conditions of the population and motivation for expansion or maintenance. We classified the set of selected roads regarding their existing environmental, social and economic conditions as shown in Table 1. We then used this information as input in the program to perform the system dynamics analysis. This allowed us to assess a preliminary indication of the environmental viability of each road, make predictions and simulate situations associated with the use of rural roads in the state. The period of time studied covers the years from 2005 through 2008.

To apply the systems dynamics method, we adopted the procedure of separating the preparation steps. First we chose the indicators based on the analysis of available documentation and data gathered. Then we analyzed these indicators and attributed weights, obtained from a simple consultation procedure, to the positive and negative factors. After that, we prepared the dynamic map, using the indicators chosen and the weights assigned, and then inserted the resulting numerical indicators in the mathematical model to perform the simulation by applying the formulas, to analyze the environmental viability of each road studied.

We considered eleven indicators, five of them positive, five negative and one that can be either positive or negative, the last one represented by the presence of local smallholders. The positive indicators were: (i) consolidated agricultural 
production; (ii) accessibility (distance to the municipal seat); (iii) infrastructure conditions of the road; (iv) public investments made in the past five years; and (v) other improvements, such as electricity, water, gas, schools and health posts. The negative factors represented the following aspects: (i) level of exploitation of natural resources; (ii) level of pollutant emissions; (iii) other environmental interferences; (iv) extent of deforestation; and (v) other negative impacts on the biota.

We assigned a weight to each indicator, as shown in Table 2, to standardize the relative values of the indicators, compose the fields necessary to formulate the proposed model and evaluate the viability of each rural road. To generate the dynamic map, we used the eleven indicators presented in Figure 1, using the weights presented in Table 3, feeding two flows, one positive and one negative, which accumulate through interaction of the positive and negative aspects.

Table 1: $\quad$ Characteristics of the rural roads considered.

\begin{tabular}{|c|c|c|c|c|}
\hline Road Name & Cambixe & Flona & Morena & Boi \\
\hline Location & Careiro da Várzea & Apuí - AM & Presidente Figueiredo & Lábrea \\
\hline Length & $23 \mathrm{~km}$ & $38 \mathrm{~km}$ & $35 \mathrm{~km}$ & $120 \mathrm{~km}$ \\
\hline Distance to municipal seat & $23 \mathrm{~km}$ & $106 \mathrm{~km}$ & $220 \mathrm{~km}$ & $140 \mathrm{~km}$ \\
\hline Investment made (if any) & $\begin{array}{l}\text { Planned but not spent } \\
\text { US } \$ 500,000.00\end{array}$ & None & US\$ $780,000.00$ & None \\
\hline Ecosystem & Floodplain and Terra Firma & Terra Firma & $\begin{array}{l}\begin{array}{l}\text { Floodplain and Terra } \\
\text { Firma }\end{array} \\
\end{array}$ & $\begin{array}{l}\text { Floodplain and Terra } \\
\text { Firma }\end{array}$ \\
\hline Families settled & 180 families & None & 185 families & 24 farms \\
\hline Agricultural production & Dairy products & None & $\begin{array}{l}\text { Manioc, fruits, stock } \\
\text { raising and fish farming }\end{array}$ & $\begin{array}{l}\text { Production not } \\
\text { consolidated }\end{array}$ \\
\hline Main market & $\begin{array}{l}\text { Careiro da Várzea, Careiro } \\
\text { Castanho and Manaus }\end{array}$ & Pará State & $\begin{array}{l}\text { Presidente Figueiredo, Vila } \\
\text { de Balbina and Manaus }\end{array}$ & Rondonia \\
\hline Improvements & Schoo, electricity & None & $\begin{array}{l}\text { Electricity, school, health } \\
\text { post }\end{array}$ & None \\
\hline $\begin{array}{l}\text { Means of transportation to } \\
\text { link to the road }\end{array}$ & River & Land & Land & $\begin{array}{l}\text { River and federal } \\
\text { highway (BR-364) }\end{array}$ \\
\hline Road conditions & $\begin{array}{l}\text { Poor, runs through } \\
\text { floodplain, unpaved, } \\
\text { pending maintenance work }\end{array}$ & $\begin{array}{l}\text { Poor, road opened illegally, } \\
\text { without maintenance work } \\
\text { planned }\end{array}$ & $\begin{array}{l}\text { Good, able to handle } \\
\text { regular traffic, ongoing } \\
\text { maintenance }\end{array}$ & $\begin{array}{l}\text { Poor, road opened } \\
\text { illegally, without } \\
\text { maintenance work } \\
\text { planned }\end{array}$ \\
\hline Traffic & $\begin{array}{l}\text { Little traffic and emission of } \\
\text { automobile exhaust gases }\end{array}$ & $\begin{array}{l}\text { Little traffic and emission } \\
\text { of automobile exhaust } \\
\text { gases, but with generation } \\
\text { of particulates }\end{array}$ & $\begin{array}{l}\text { Little traffic and emission } \\
\text { of automobile exhaust } \\
\text { gases }\end{array}$ & $\begin{array}{l}\text { Little traffic and emission } \\
\text { of automobile exhaust } \\
\text { gases }\end{array}$ \\
\hline $\begin{array}{l}\text { Generation of impacts } \\
\text { (biota) }\end{array}$ & $\begin{array}{l}\text { Loss of flora, fauna and } \\
\text { other natural resources along } \\
\text { the route }\end{array}$ & $\begin{array}{l}\text { Loss of flora, fauna and } \\
\text { other natural resources } \\
\text { beyond the area of the road }\end{array}$ & $\begin{array}{l}\text { Loss of flora, fauna and } \\
\text { other natural resources } \\
\text { along the route }\end{array}$ & $\begin{array}{l}\text { Loss of flora, fauna and } \\
\text { other natural resources } \\
\text { beyond the area of the } \\
\text { road }\end{array}$ \\
\hline $\begin{array}{l}\text { Exploitation of natural } \\
\text { resources }\end{array}$ & $\begin{array}{l}\text { Stock breeding in the } \\
\text { floodplain Hunting } \\
\text { and forest extraction with } \\
\text { medium intensity }\end{array}$ & $\begin{array}{l}\text { Logging speculation, heavy } \\
\text { exploitation of existing } \\
\text { resources }\end{array}$ & $\begin{array}{l}\text { Hunting and forest } \\
\text { extraction with medium } \\
\text { intensity }\end{array}$ & $\begin{array}{l}\text { Attempted interference } \\
\text { with water course }\end{array}$ \\
\hline $\begin{array}{l}\text { Environmental } \\
\text { interference }\end{array}$ & $\begin{array}{l}\text { Floodplain area } \\
\text { Stock breeding }\end{array}$ & $\begin{array}{l}\text { Road on terra firma } \\
\text { Burning }\end{array}$ & Road on terra firma & $\begin{array}{l}\text { Road on terra firma } \\
\text { Attempted interferince } \\
\text { with water course }\end{array}$ \\
\hline
\end{tabular}




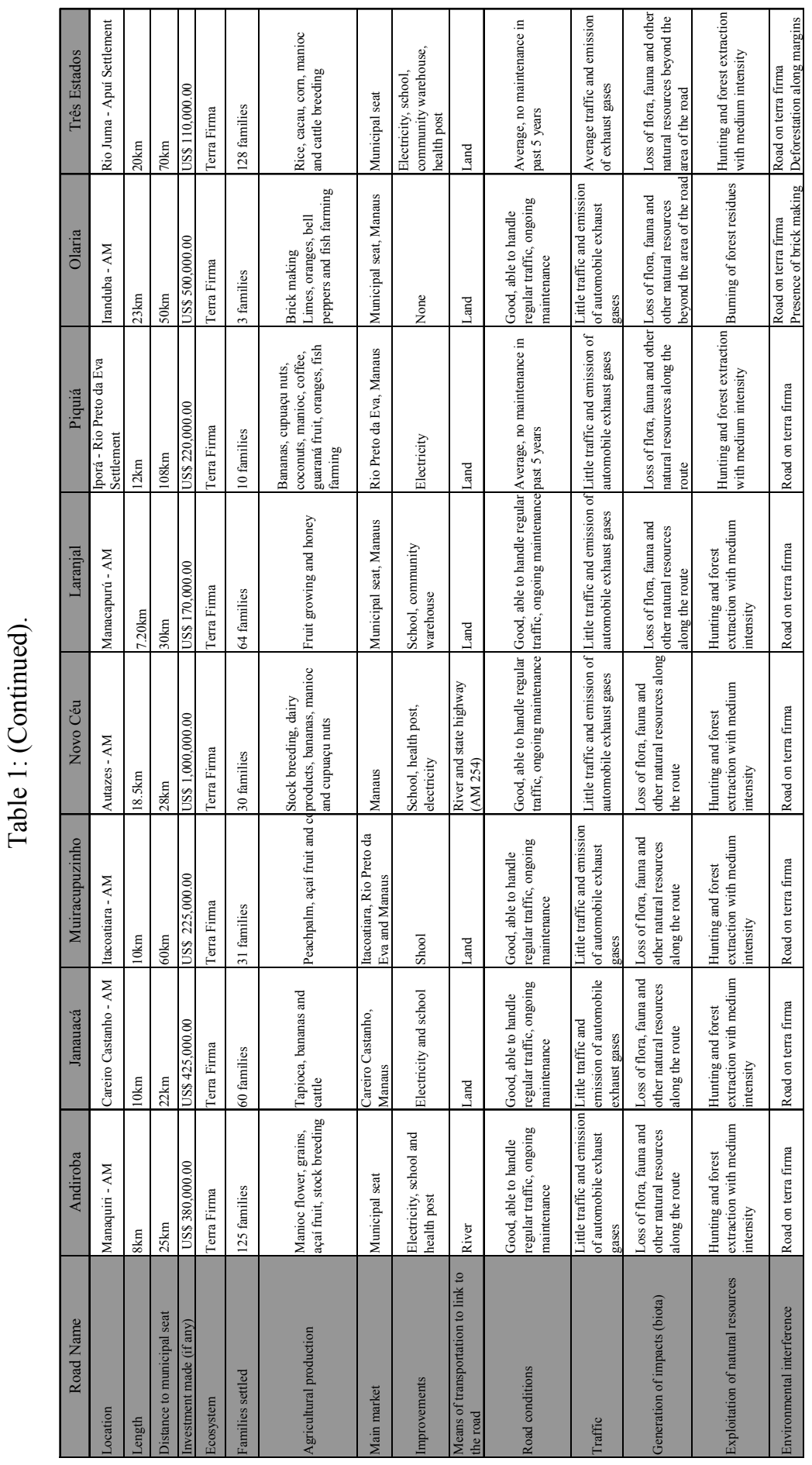

WIT Transactions on Ecology and the Environment, Vol 127, (c) 2009 WIT Press www.witpress.com, ISSN 1743-3541 (on-line) 
116 Management of Natural Resources, Sustainable Development and Ecological Hazards II

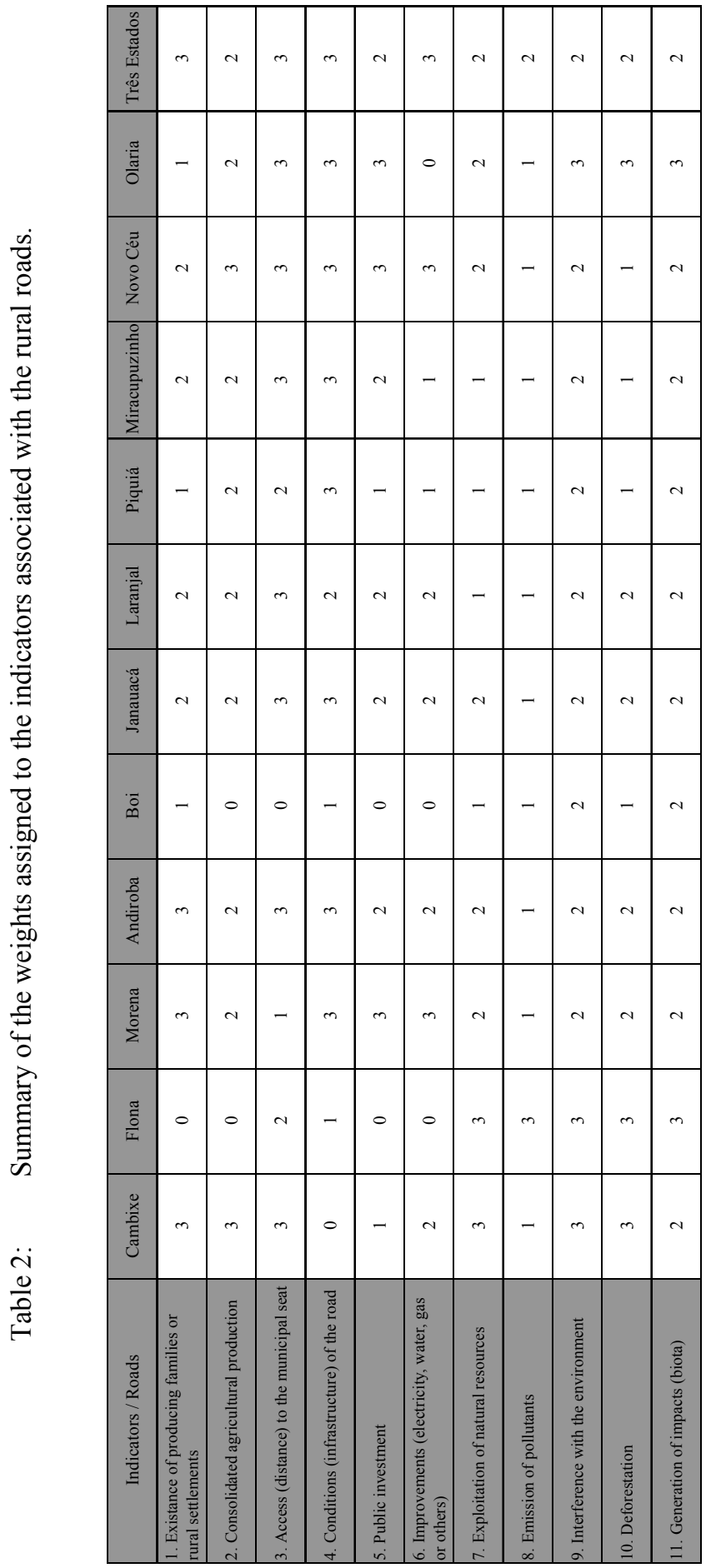


The positive flow starts with the number of families living along the road, who are responsible for the local agricultural output (plant and animal products). Their presence in turn prompts public investments. These resources generate improvements in the environs of the road, which improve the infrastructure conditions along the road and provide better access to the municipal seats.

The negative flow also starts with the number of families living along the road, because the disordered occupation of the surrounding areas contributes directly to deforestation for wood and other natural resource exploitation or use as farmland. The consequent burning of underbrush emits pollutants that, depending on the local ecosystem, can trigger significant negative impacts on the biota.

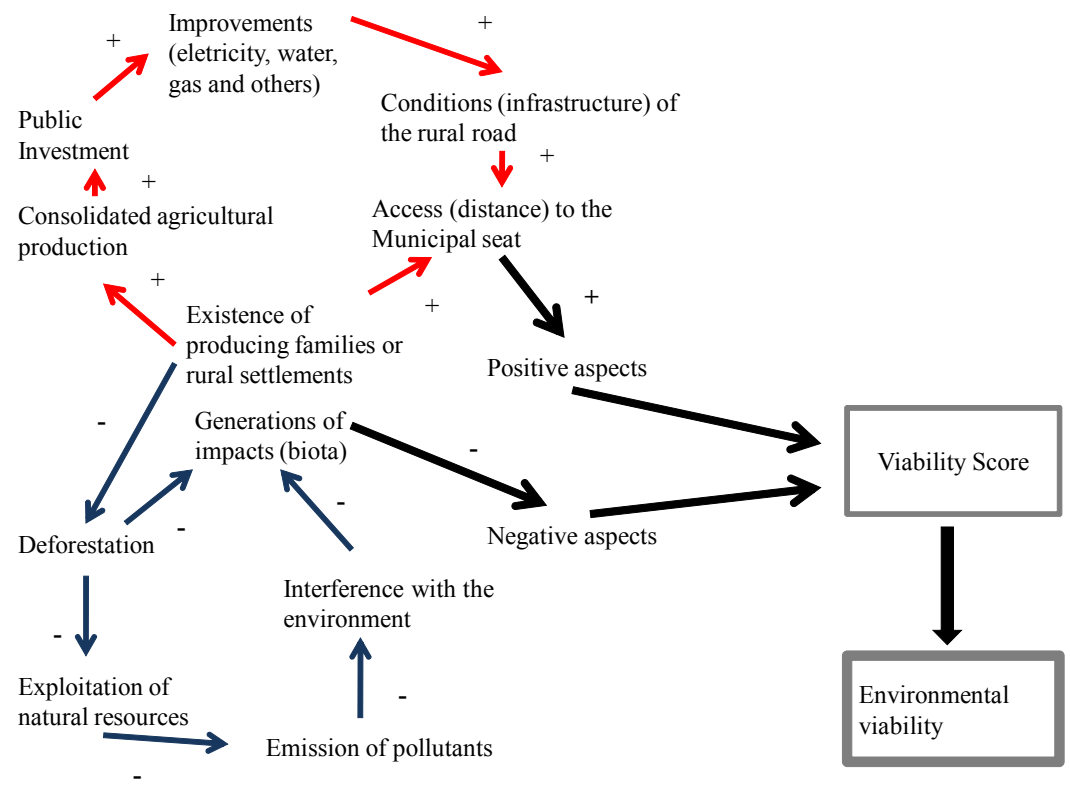

Figure 1: Viability study map of the rural roads.

\section{Analysis of the environmental viability of rural roads in the Amazon region}

Based on the eleven indicators established to analyze the twelve rural roads in the Amazon region and their causality network established by the system dynamics technique, we determined that eight are environmentally viable and four are not. These results are summarized in Table 3.

The roads that are not viable are Cambixe, Flona, Boi and Olaria, where the negative impacts outweigh the positive ones. The environmentally viable roads are Morena, Andiroba, Janauacá, Laranjal, Piquiá, Muiracupuzinho, Novo Céu and Três Estados. 
Table 3: $\quad$ Summary of the results of the dynamic simulation.

\begin{tabular}{|c|c|c|c|c|}
\hline Rural Road & $\begin{array}{c}\text { Aggregated } \\
\text { Positive } \\
\text { Aspects }\end{array}$ & $\begin{array}{c}\text { Aggregated } \\
\text { Negative } \\
\text { Aspects }\end{array}$ & $\begin{array}{c}\text { Viability Index } \\
\text { Score }\end{array}$ & $\begin{array}{c}\text { Environmental } \\
\text { Viability }\end{array}$ \\
\hline CAMBIXE & 15 & 21 & -6 & no \\
FLONA & 3 & 18 & -15 & no \\
MORENA & 20 & 16 & 4 & yes \\
ANDIROBA & 18 & 17 & 1 & yes \\
BOI & 3 & 10 & -7 & no \\
JANAUACÁ & 16 & 15 & 1 & yes \\
LARANJAL & 15 & 14 & 1 & yes \\
PIQUIÁ & 11 & 10 & 1 & yes \\
MIRACUPUZINHO & 15 & 12 & 3 & yes \\
NOVO CÉU & 19 & 13 & 6 & yes \\
OLARIA & 13 & 17 & -4 & no \\
TRÊS ESTADOS & 19 & 18 & 1 & yes \\
\hline
\end{tabular}

Among the environmentally non-viable roads, the worst performers are Flona and Boi. In these two cases the potentially positive factors are either zero or have low weights, due to the absence of nearby families and the low levels of public investment, improvements and consolidated agricultural output. In turn, the negative factors are strong, due to the presence of deforestation, atmospheric pollution and improper exploitation of natural resources. The final scores from considering the weighted summation of factors for the Flora and Boi roads are 15 and -7 , respectively.

In the case of the Cambixe road, also considered environmentally non-viable with an aggregate result of -6 , the main negative factor is environmental interference, since it runs through a floodplain area. This means the road is often difficult or impossible to use, meaning low accessibility for the region it serves.

Olaria Road, also considered not environmentally viable, serves a small number of families, but the production of the area served has significant presence of brick making, which generates relevant negative impacts from the extraction of clay and wood, producing significant amounts of residues. This means it plays a major role in deforestation and other negative impacts on the local biota. Another factor that stands out is the small presence of public investments in local infrastructure. The environmental viability value is -4 , which also includes it among the roads not environmentally viable.

With respect to the rural roads determined to be environmentally viable, the following points stand out:

- The roads with the highest aggregate environmental viability scores, in tallying the positive and negative impacts, are Morena, Muiracupuzinho and Novo Céu. For all of them the positive factors outweigh the negative ones by a good margin. In the particular case of Muiracupuzinho, which obtained a score of 3 , it has the advantage of proximity of the area served to the municipal seat, besides the presence 
of public investments in roadway infrastructure. Furthermore, perhaps because of this proximity, the negative environmental impacts are smaller, contributing to its viability;

- The other roads classified as environmentally viable - Andiroba, Janauacá, Laranjal and Piquiá - obtained aggregate scores of only 1, indicating a near balance between the negative and positive impacts. The positive ones prevail mainly because of investments in infrastructure and the consequent promotion of high levels of accessibility.

\section{Conclusions}

Determination of the environmental viability of the rural roads considered in this study, due to the nature of the system dynamics technique adopted, depends essentially on the causality network prepared to model the interaction of the indicators chosen, along with the weights assigned to the indicators. We obtained these from the opinion of specialists with knowledge of the local and regional conditions. The results reveal that only four of the roads considered - Cambixe, Flona, Boi and Olaria - are not environmentally viable.

The indicator of the number of families settled near each road in this simulation is a very important factor. The roads associated with larger communities, such as Morena, Andiroba and Três Estados, showed positive environmental viability values. This fact can point to a question of great importance in evaluating transportation investments, especially in roads, in the Amazon region. In other words, the positive result of rural roads that provide access to larger communities did not clearly indicate that occupation of areas near roads leads to degraded environmental quality. In reality, there is evidence suggesting that occupation along roads, allied with specific planning and environmental preservation strategies, can aggregate benefits to the places served by these roads.

With respect to public policies, the roads accompanied by public investments in infrastructure, due to their links with organized settlements, represented by Piquiá and Três Estados, have good results in terms of environmental viability. In contrast, roads opened irregularly, without any government intervention, such as Flona and Boi, have negative scores because of the absence of public investments in infrastructure and other improvements, along with the lack of consolidated production from legal activities in lieu of uncontrolled exploitation of natural resources, causing environmental degradation.

Agricultural output, considering its form, composition and intensity, assumes an important rule in the process of evaluating the environmental viability of roads in the Amazon region because of the supply of products they enable to the respective municipal center cities. This is not the case, as shown by the results, for Flona and Boi roads, which have no consolidated agricultural activity. 
It is important to note also that the access of the communities studied to the main nearby consuming centers, provided by the characteristics of the local roads associated with them, is an essential element to assure positive environmental viability scores. Communities with easier access also tend to show clearer signals of agricultural organization and administration. Also noteworthy is the positive relation between the rural roads that receive higher public investments in improvements for the communities served by them and those that present better environmental quality characteristics. This runs counter to evidence suggesting that greater land occupation automatically means greater negative environmental impact. This relationship can be fragile if there is strong presence of public authorities imposing specific policies to organize the occupation and assure access to rural communities.

The importance of identifying and selecting public investments according to local peculiarities is shown by the case of Olaria Road, which did not obtain a positive score despite the small number of families settled near it and the significant public investments made. This is possibly due to the main economic activity there in relation to the nature of the investments made.

In the case of rural roads classified as not environmentally viable, the system dynamics model allowed identifying possible priority actions to reverse this situation. Among these is promotion of regional development, whether by investing in roadway infrastructure or adopting strategies to organize land occupation and to preserve the environment.

This preliminary study shows that providing access through roadway infrastructure can provide greater development and better quality of life in rural communities in the Amazon without neglecting the need to control natural resource exploitation and to preserve the environment.

\section{References}

[1] Jaarsma, C.F., Dijk, T. (2002). Financing local rural road maintenance. Who should pay what share and why? Transportation Research $A, 36$. pp. 507-524, 2002.

[2] Escobal, J., Ponce, C., El beneficio de los caminos rurales: ampliando oportunidades de ingreso para los pobres. Documento de Trabalho 40. Grade. Available at www.nip-lac.org/docs_meeting2002/ EscobalRural\%20Roads\%20June.pdf. Accessed on December 15, 2005.

[3] Jacoby, H. G., Access to Markets and the Benefits of Rural Roads: A Nonparametric Approach. The World Bank. Washington DC. 30p., 1999.

[4] Jaarsma, C.F., Approaches for the planning of rural road network according to sustainable land use planning, Landscape and Urban Planning, 39, pp. 47-54, 1997

[5] Soares-Filho, B.S., Nepstad, D., Curran L., Scenarios for Amazon Deforestation, Estudos Avançados, São Paulo, 19, pp. 138-152, 2005.

[6] Santos, M. J. C. Viabilidade Econômica em Sistemas Agro florestais nos Ecossistemas de Terra Firme e Várzea no Estado do Amazonas: Um 
estudo de casos. Thesis presented to the Luiz de Queiroz Superior School of Agriculture, University of São Paulo. Piracicaba, S.P., 142p., 2004.

[7] Forrester, J.W., Industrial Dynamics, Pegasus Communications, 1961.

[8] Lane, D.C., The power of the bond between cause and effect: Jay Wright Forrester and the field of system dynamics. Systems Dynamic Review, 23, pp. 95-118, 2007.

[9] Checchinato, D., Modelagem de problemas logísticos sob o enfoque de sistemas dinâmicos: o caso do jogo da cerveja. MSc dissertation, Florianópolis, Brazil, 2002. Available at: http://teses.eps.ufsc.br. Accessed in December 2007.

[10] Gary, M.S., Kunc, M., Morecroft, J.D.W., Rockart, S.F., Systems dynamics and strategy. Systems Dynamic Review, 24, pp. 407-429, 2008.

[11] Hjortha, P; Bagheria, P., Navigating towards sustainable development: A system dynamics approach. Futures, 38, pp. 74-92, 2006.

[12] Leal-Neto, A. C., A expansão do terminal de contêineres de Sepetiba: uma aplicação da dinâmica de sistemas e considerações ambientais. MSc Dissertation, Federal University of Rio de Janeiro (UFRJ), Rio de Janeiro, Brazil, 2000.

[13] Ventana Inc., Vensim reference manual. Ventana Systems Inc., Revision Date, Harvard, MA, USA, 2007 